\title{
EVALUASI IMPLEMENTASI KEBIJAKAN PUBLIK TERHADAP PERATURAN DAERAH BERMASALAH
}

\author{
Femmy Silaswaty Faried, Suparwi; Universitas Islam Batik Surakarta, Jl. KH Agus Salim No. 10 \\ Surakarta; E-mail: femmysilaswaty@gmail.com
}

\begin{abstract}
Abstrak
Evaluasi terhadap implementasi kebijakan publik yang keluar akibat dari suatu peraturan daerah bermasalah, adalah dapat dilakukan untuk menelaah apakah suatu kebijakan yang keluar tersebut adalah tepat untuk pelaksanaan suatu peraturan daerah yang belum aplikatif, dan dalam hal ini menurut peneliti adalah merupakan suatu peraturan daerah yang juga masuk dalam kategori bermasalah. Peraturan daerah bermasalah yang dimaksud peneliti adalah tidak hanya karena peraturan daerah tersebut bertentangan dengan peraturan yang lebih tinggi, tidak juga karena peraturan daerah tersebut melanggar norma-norma kesusilaan, tetapi bagi peneliti peraturan daerah yang bermasalah juga termasuk jika didalamnya aturannya tidaklah aplikatif, sehingga membutuhkan aturan lebih lanjut agar peraturan daerah tersebut dapat aplikatif.
\end{abstract}

Kata kunci: Evaluasi, Kebijakan Publik, Peraturan Daerah

\begin{abstract}
Evaluation of the implementation of public policy coming out of a regulation of the problematic area, it is possible to study whether a policy that comes out is appropriate for the implementation of a local regulation that has not been And in this case according to researchers is a regional regulation which also goes into problematic category. The problem of the problematic area of the researcher is not only because the regulation of the area is contrary to higher regulations, nor because the local regulation violates the norms of morality, but for researchers Local regulations are also included if the rules are not applicative, so it requires further rules to be applicative to the local regulations.
\end{abstract}

Keywords: Evaluation, Public Policy, Local Regulations

\section{PENDAHULUAN}

Peraturan daerah merupakan salah satu instrumen regulatif yang bersifat vital untuk menjalankan visi, misi, dan program yang telah ditetapkan oleh kepala daerah. Dengan demikian peraturan daerah pada dasarnya merupakan penjabaran dari visi, misi, dan program seorang kepala daerah dalam menjalankan roda pemerintahannya. Dalam hierarkhi peraturan perundang-undangan peraturan daerah merupakan salah satu produk legislasi yang diakui eksistensinya secara konstitusional. ${ }^{1}$ \footnotetext{
konstitusional adalah sebagai berikut:

1. UUD NKRI Tahun 1945

2. Ketetapan MPR

3. Undang-Undang/Peraturan Pemerintah Pengganti Undang-Undang

4. Peraturan Pemerintah

5. Peraturan Presiden

6. Peraturan Daerah Provinsi, dan
}

1 Pasal 7 Undang-Undang Nomor 12 Tahun 2011 tentang Pembentukan Peraturan PerundangUndangan, menegaskan bahwa hierarkhi peraturan perundang-undangan yang dikenal secara 
Sebagai instrumen regulatif, peraturan daerah tentunya merupakan suatu sarana yang bersifat mengatur dan oleh karena itu harus bersifat aplikatif sehingga dapat diimplementasikan kedalam setiap langkah kebijakan pemerintah daerah. Dengan demikian sesungguhnya implementasi peraturan daerah merupakan suatu faktor kunci dari terwujudnya tujuan pemerintah daerah. Di sisi lain tujuan pemerintah daerah tidak akan pernah tercapai apabila peraturan daerah yang telah ada tidak dapat terimplementasikan.

Peraturan daerah yang tidak dapat terimplementasikan pada prinsipnya dapat dikategorikan sebagai "peraturan daerah bermasalah". Kategori tersebut akan timbul manakala terjadi kesulitan dalam mengimplementasikan peraturan daerah dimaksud, atau bahkan timbul manakala suatu peraturan daerah sama sekali tidak dapat terimplementasikan. Dalam prakteknya seringkali kepala daerah menetapkan peraturan kepala daerah (Peraturan Bupati/walikota) sebagai suatu instrumen yang menjamin tetap tercapainya tujuan suatu peraturan daerah. Peraturan kepala daerah sesungguhnya tidak dikenal dalam jenis dan hierarkhi sebagaimana dimaksud dalam Undang-Undang Nomor 12 Tahun 2011 tentang Pembentukan Peraturan Perundang-Undangan, namun eksistensi peraturan kepala daerah banyak dikenal sebagai bentuk kebijakan kepala daerah untuk melaksanakan suatu peraturan daerah. Tidak dikenalnya peraturan kepala daerah dalam hierarkhi peraturan perundang- undangan sesungguhnya merupakan suatu pernyataan tegas Undang-Undang Nomor 12 tahun 2011 mengenai urgensi dari peraturan kepala daerah tersebut. Di sisi lain tidak dikenalnya peraturan kepala daerah dalam hierarkhi peraturan perundang-undangan sesungguhnya juga merupakan penegasan adanya sifat implementatif dari suatu peraturan daerah, sehingga manakala suatu perda lahir dapat langsung diimplementasikan tanpa adanya suatu masalah/kendala.

Masalah atau kendala dalam pelaksanaan peraturan daerah merupakan anasiranasir yang menyebabkan suatu peraturan daerah tidak dapat langsung diimplementasikan. Sebagai contoh, suatu perda yang mengatur tentang Retribusi daerah tidak dapat langsung diimplementasikan akibat dari tidak adanya penegasan mengenai tarif retribusi. Terhadap peraturan daerah ini_tentunya harus diiringi dengan suatu peraturan kepala daerah tentang besaran tarif retribusi untuk menjamin tetap terlaksananya peraturan daerah dimaksud.

Kebijakan publik berupa peraturan kepala daerah seringkali mampu membantu tercapainya suatu tujuan peraturan daerah, sehingga implementasi peraturan kepala daerah tersebut secara evaluatif dipandang sebagai kebijakan publik yang tepat sebagai solusi terlaksanakannya suatu peraturan daerah bermasalah. Namun demikian apabila peraturan kepala daerah yang telah ditetapkan ternyata bukan merupakan instrumen yang dapat membantu tercapainya tujuan peraturan daerah, maka secara evaluatif implementasi kebijakan publik terhadapnya akan dipandang sebagai suatu kebijakan publik yang bersifat tidak kontributif dalam mencapai tujuan peraturan daerah.

7. Peraturan Daerah Kabupaten/Kota 
Suatu perda yang masuk dalam kategori perda bermasalah yang disebabkan karena isi perda tersebut tidak jelas dalam pengaturannya, bahkan tidak memiliki aturan pelaksana lebih lanjut, adalah dapat disikapi dengan adanya kebijakan yang kemudian muncul melalui suatu proses yang sesuai. Kebijakan yang dimaksud disini adalah suatu kebijakan publik yang implementasi dari kebijakan tersebut memberikan suatu hasil dari peraturan perundang-undangan yang dapat dilaksanakan. Sehingga nantinya tidak akan ada lagi perda perda yang harus dibatalkan, dikarenakan perda tersebut bermasalah.

Tahun 2016, Presiden Joko Widodo menyampaikan pada wartawan di Istana merdeka, bahwa:

“Saya sampaikan bahwa Menteri Dalam Negeri sesuai dengan kewenangannya

telah membatalkan 3.143 peraturan daerah yang bermasalah," ditambahkan lagi oleh bapak Presiden bahwa:

"Saya sudah perintahkan Kementerian Dalam Negeri hapuskan 3.000 Perda, tak perlu dikaji lagi. Nggak perlu kaji- kajian kalau mau hapuskan."

Sejumlah aturan yang dibatalkan ini meliputi perda yang menghambat pertumbuhan ekonomi daerah dan memperpanjang jalur birokrasi. Kemudian perda yang menghambat proses perizinan dan investasi, perda yang menghambat kemudahan usaha, dan perda yang bertentangan dengan peraturan perundangan yang lebih tinggi.

Perda yang dibatalkan tersebut menyangkut kepentingan publik atau hajat hidup orang banyak, jika dicermati bahwa perda yang lahir adalah cenderung lebih mengarah dengan semangat meningkatkan Pendapatan Asli Daerah yang selanjutnya disebut PAD dengan tidak memperhatikan sejumlah aturan yang lebih tinggi juga mengesampingkan kepentingan rakyat daerah atau tidak mengindahkan serta memperhatian kelestarian lingkungan bahkan ditemukan pula perda yang berpotensi menimbulkan korupsi yang dimaksudkan untuk memperkaya diri sendiri dan juga korporasi.

Ribuan perda bermasalah harus dapat ditindak lanjuti, selain dengan cara mencabut serta melakukan revisi aturan tersebut, dapat juga dengan cara pengujian atau evaluasi terhadap perda yang bermasalah tersebut. Strategi yang dipergunakan adalah dengan melibatkan masyarakat dalam pelaksanaan evaluasi, koreksi serta pengawasan melalui kegiatan eksaminasi publik. Eksaminasi publik adalah suatu cara untuk mewujudkan peran serta masyarakat dalam melakukan koreksi terhadap suatu produk hukum yang bermasalah. Peran serta masyarakat tersebut sebagaimana telah diatur didalam Pasal 139 ayat (1) dan ayat (2) UU No. 32 Tahun 2004 tentang Pemerintahan Daerah:

1. Masyarakat berhak memberikan masukan secara lisan atau tertulis dalam rangka penyiapan atau pembahasn rancAngan perda;

2. Persiapan pembentukan, pembahasan dan pengesahan rancangan perda berpedoman kepada peraturan perundang-undangan.

Menurut penulis adanya perda bermasalah adalah sebagai akibat tarik ulur antara pusat dan daerah. Negara kesatuan kita yang menghendaki eenheidstaat sedangkan 
otonomi daerah menghendaki autonomostaat. Perbedaan inilah yang mencuatkan persoalan. Suatu kebijakan hukum yang dibuat adalah tidak mudah dengan melihat keberagaman yang ada di negara kita Indonesia. Pembuatan kebijakan hukum untuk kepentikan publik adalah bukan merupakan suatu persoalan mudah, semuanya dapat dipolitisasi, dengan dalih berlindung pada demokrasi, pada hak asasi manusia, pemerataan dan atau kesenjangan.

Dalih yang dipergunakan malah bukan menghasilkan solusi namun tidak sedikit menimbulkan permasalahan dan polemik sehingga dapat berujung pada gerakan separatis yang dapat memancing emosi nasionalisme. Persoalan inkonsistensi suatu aturan hukum akibat tarik ulur kewenangan tersebut memunculkan problema hukum dengan tidak terpenuhinya kepastian hukum.

Untuk mengantisipasi perda yang tidak aplikatif tersebut, maka diperlukanlah adanya suatu kebijakan yang disebut kebijakan publik yang mana pembuatan kebijakan tersebut tidak boleh lepas dari tujuan dibuatnya perda tersebut, sehingga tidak akan lagi terjadi pembatalan terhadap perda- perda bermasalah, bahkan meminalisir perda yang tidak aplikatif. Penulisan penelitian ini akan merujuk pada suatu kebijakan yang dibuat oleh pemerintah dalam hal ini kebijakan publik yang akan menjadi suatu kebijakan yang nantinya akan membantu suatu perda dapat terlaksana sesuai dengan maksud dan tujuannya.

Kebijakan publik yang dimaksud dalam penelitian ini adalah suatu kebijakan yang dievaluasi implementasinya, apakah kebijakan tersebut mampu menjadikan perda menjadi aplikatif dan efektif serta efisien juga mencapai tujuan dari perda tersebut. Satu kebijakan sebelum dapat dievaluasi tentu saja melalui proses, proses yang dimaksud adalah suatu proses pembuatan kebijakan. Apakah hasil dari perumusan kebijakan tersebut memiliki

Untuk merumuskan suatu kebijakan tersebut terlebih dahulu dilakukan suatu analisa kebijakan menuju proses kebijakan. Sebagaimana pendapat dari Raymond A. BAUER dalam bukunya "The Study of Policy Formation (1968), yang telah diterjemahkan, mengatakan bahwa perumusan kebijakan adalah proses sosial di mana proses intelektualmelekat di dalamnya tidak berarti bahwa efektifitas relatif dari proses intelektual tidak dapat ditingkatkan, atau bahwa proses sosial dapat "diperbaiki"2.

Hal ini menunjukkan bahwa suatu proses kebijakan diperlukan adanya suatu ilmu pengetahuan yang sesuai dengan bidangnya sehingga mampu mengetahui, suatu sebab, akibat dan kinerja kebijakan dan program publik, agar kebijakan yang nantinya terbentuk jelas memberikan suatu kebijakan yang aplikatif dan seiring dengan peraturan daerah. Dalam proses menciptakan pengetahuan dan intelektual tersebut adalah untuk meneliti sebab akibat dan kinerja serta program publik itulah yang dimaksud dengan suatu proses analisa terhadap kebijakan yang akan timbul nantinya. Analisa terhadap pengambilan kebijakan tentu saja harus sesuai dengan prosedur, metodologi hingga

${ }^{2}$ William N. Dunn, Pengantar Analisis Kebijakan Publik Edisi kedua, Gadjah Mada University Press: Cetakan Kelima Maret 2003, h. 1. 
akhirnya dapat dievaluasi dengan baik. Evaluasi implementasi suatu kebijakan dapat dilihat dengan cara kesesuaian antara kinerja kebijakan yang diharapkan dengan yang benar-benar dihasilkan sehingga membantu dalam pembuatan kebijakan.

Dalam merumuskan suatu kebijakan publik yang merupakan wewenang seorang pejabat sebagaimana yang diatur kewenangan dalam peraturan perundang-undangan tentu saja mengutamakan nilai-nilai demokrasi. Nilai-nilai demokrasi yang dimaksud adalah agar semua elemen masyarakat akan merasa memiliki kebijakan tersebut, karena kebijakan publik tersebut mampu mengakomodasi semua kepentingan. Ketika suatu kebijakan yang dibuat tidak mampu mengakomodasi tuntutan masyarakat maka tidak mempunyai legitimasi dan tidak memenuhi rasa keadilan. Pada intinya keputusan dan pembuatan kebijakan publik oleh pemerintah adalah "public policy consist of political decisions for implementing program to achieve societal goals."

Kewenangan dalam pembuatan kebijakan publik adalah merupakan kewenangan eksekutif, dalamhal ini kebijakan publik yang timbul dan memberikan suatu aturan yang aplikatif terhadap ti ndak lanjut dari suatu perda yang tidak aplikatif, sebagaimana yang disebutkan oleh Jimly Assshiddiqie dalam Sirajuddin, Didik Sukriono dan Winardi, adalah: mencatat bahwa dalam hampir semua sistem yang ada sekarang pihak eksekutif telah menjadi cabang kekuasaan yang lebih dominan pengaruh dan perannya sebagai sumber inisiatif pembentukan peraturan perundang- undangan. ${ }^{4}$

Kewenangan dalam pembuatan kebijakan publik adalah merupakan kewenangan eksekutif, dalam hal ini kebijakan publik yang timbul dan memberikan suatu aturan yang aplikatif terhadap tindak lanjut dari suatu perda yang tidak aplikatif, sebagaimana yang disebutkan oleh Jimly Assshiddiqie dalam Sirajuddin, Didik Sukriono dan Winardi, adalah:mencatat bahwa dalam hampir semua sistem yang ada sekarang pihak eksekutif telah menjadi cabang kekuasaan yang lebih dominan pengaruh dan perannya sebagai sumber inisiatif pembentukan peraturan perundang-undangan. ${ }^{5}$ Dalam perspektif kajian kebijakan publik, eksekutif dimanapun pada umumnya mempunyai dua tugas dan kewenangan utama yakni apa yang disebut dengan kewenangan yang bersifat administratif dan kedua kewenangan politik. Tugas dan kewenangan administratif melekat pada jabatan seorang eksekutuf yang sehari-harinya harus mengendalikan roda pemerintahan. Menurut Leonardo D. White dalam Sirajuddin, Didik Sukriono dan Winardi, menyingkatnya POSDCORB yaitu singkatan dari Planning, Organizatio, Staffing, Directing, Coordinating, and Budgetting. ${ }^{6}$

Penetapan kebijakan publik oleh pemerintah daerah dalam hal ini untuk mewujudkan suatu perda yang aplikatif, agar tidak lagi terjadi ataupun meminimalisir peraturan daerah yang bermasalah, adalah kewenangan lembaga eksekutif, yang diadalm pemerintahan daerah yaitu Kepala daerah. Kepala derah adalah pimpinan eksekutif di

3Surya Fermana, Kebijakan Publik Sebuah Tinjauan Filosofis, AM Media, 2009, h. 39.

"Sirajuddin, Didik Sukriono dan Winardi, Hukum Pelayanan Publik Berbasis Partisipasi dan Keterbukaan Informasi, 2011, h. 46.

5Ibid, h. 46.

6Ibid, h. 46. 
lingkungan pemerintahan daerah. Kepala daerah propinsi adalah gubernur, Kepala daerah kabupaten adalah bupati dan kepala daerah kota adalah walikota.

Kebijakan publik yang dikeluarkan melalui keputusan kepala daerah baik keputusan kepala daerah ditingkat propinsi maupun ditingkat kabupaten/kota, adalah berdasarkan kewengan yang dimilikinya. Menurut teori kewenangan diadalam hukum tata negara kewenangan yang dimiliki oleh kepada daerah ditingkat provinsi dalam hal ini adalah gubernur, kewenangan yang dimilikinya adalah kewenangan atribusi dan kewenangan delegasi.

Kebijakan publik yang dikeluarkan melalui keputusan kepala daerah ditingkat provinsi yang dimaksud adalah keputusan kepala daerah berdasarkan kewenangan atribusi yang dimilikinya, yang mana bahwa kewenangan tersebut dipergunakan untuk merumuskan suatu kebijakan karena diamanatkan oleh peraturan perundang-undangan, yaitu untuk mencapai suatu aturan perda yang aplikatif maka dikeluarkan lah suatu kebijakan publik. Sebagai contoh adalah Peraturan kepala daerah yaitu peraturan Gubernur Pergub DKI Jakarta No. 88 Tahun 2019 tentang Kawasan Dilarang Merokok, adalah merupakan kelanjutan dari Perda Provinsi DKI Jakarta No. 2 Tahun 2005 tentang Pengendalian Pencemaran Udara. Untuk mengendalikan pencemaran udara terjadi sebagaimana yang diatur dalam Perda tersebut, maka dibuatlah suatu peraturan gubernur menyangkut kawasan dilarang merokok, sehingga jelas bahwa peraturan kepala daerah tersebut adalah merupakan kebijakan publik yang diambil agar perda terkait pengendalian pencemaran udara dapat terlaksana/aplikatif.

\section{RUMUSAN MASALAH}

Berdasarkan uraian pada latar belakang tersebut, maka peneliti merumuskan permasalahan dalam penelitian ini adalah sebagai berikut:

Apakah evaluasi implementasi kebijakan publik pada peraturan daerah bermasalah dapat mewujudkan sistem pemerintahan daerah dengan asas otonomi daerah?

\section{METODE PENELITIAN}

Peneliti berpandangan bahwa banyaknya suatu peraturan daerah yang bermasalah, dan selanjutnya diterapkan adanya peraturan lebih lanjut yang menjelaskan dan mengatur secara lanjut isi peraturan daerah yang dimaksud. Peraturan yang mengatur lebih lanjut, inilah yang disebut sebagai suatu kebijakan, kebijakan yang dikeluarkan oleh kepala daerah yang memiliki kewenangan sebagaimana yang diatur dalam peraturan perundang-undangan. Peneliti melihat bagaimana suatu kebijakan yang keluar tersebut dapat memberikan pengaturan lebih lanjut dan jelas dan sesuai dengan isi dari peraturan daerah. Oleh karena itu dibutuhkan evaluasi implementasi kebijakan publik tersebut.

Penelitian ini menggunakan metode penelitian hukum normatif, menggunakan data sekunder berupa bahan hukum primer yang bersumber dari peraturan perundang- 
undangan yang dipakai serta artikel-artikel yang berhubugan dengan tulisan ini.

\section{KAJIAN TEORITIS}

\section{Tinjauan Umum Tentang Kebijakan}

\section{a. Pengertian Kebijakan dan Kebijakan Publik}

Peraturan perundang-undangan dalam bentuk peraturan daerah adalah produk hukum dari pemerintah daerah yang merupakan lembaga legislatif didaerah yang sama halnya dengan lembaga legislatif di tingkat pusat. Perihal peraturan daerah tentu saja sebagaimana yang dipaparkan pada bagian pendahuluan adalah tidak dapat serta merta diberlakukan dengan dikarenakan beberapa hal, oleh karena itu dibutuhkan beberapa tindakan oleh pemerintah dalam bentuk mengambil suatu langkah tindakan dan keputusan dalam hal ini kebijakan, terhadap perda tersebut jika perda tersebut ternyata diperlukan kebijakan yang dapat ditetapkan agar perda tersebut dapat dijalankan dengan baik. Dalam kamus Bahasa Indonesia kebijakan berasal dari kata bijak yang berarti pandai, mahir. Kebijakan berarti kepandaian, kemahiran, kebijaksanaan, dalam suatu rangkaian konsep dan azas yang menjadi garis besar dan dasar rencana pelaksanaan suatu pekerjaan, kepemimpinan dan cara bertindak dalam pemerintahan atau organisasi sebagai pernyataan cita-cita, tujuan, prinsip atau maksud sebagai garis pedoman untuk manajemen dalam usaha mencapai sasaran. ${ }^{7}$

\section{b. Unsur Kebijakan Publik}

Selanjutnya beberapa unsur dari kebijakan publik yang dapat dikategorikan sebagai sub sub sistem dalam suatu sistem, yaitu sistem yang dimaksud adalah kebijakan publik itu sendiri, antara lain:

1. Unsur tujuan kebijakan

2. Unsur masalah

3. Unsur tuntutan (demand)

4. Unsur dampak atau Outcomes dan

5. Unsur sarana atau alat kebijakan (policy instrument)

Kelima unsur tersebut adalah suatu rangkain yang ada dalam menyusun dan merumuskan suatu kebijakan publik.

\section{c. Ciri Umum Kebijakan Publik}

Menurut Wahab dalam Irawan Suntoro dan Hasan Hariri, 2015. Ciri-ciri kebikan publik berimplikasi terhadap konsep kebijakan publik, sebagai berikut:

1. Kebijakan publik lebih merupakan tindakan yang sengaja dilakukan dan mengarah pada tujuan tertentu, dari pada sekedar sebagai bentuk perilaku atau tindakan yang menyimpang asal- asalan dan serba kebetulan;

2. Kebijakan pada hakekatnya terdiri atas tindakan-tindakan yang saling berkaittertentu yang dilakukan oleh pejabat-pejabat pemerintah dan bukan

7Irawan Suntoro dan Hasan Hariri, Kebijakan Publik. Bandar Lampung: Graha Ilmu, 2015, h. 1. 
keputusan-keputusan yang berdiri sendiri;

3. Kebijakan itu ialah sesuatu yang nyatanya dilakukan oleh pemerintah dalam bidang tertentu, misalnya: dalam mengatur perdagangan, mengendalikan inflasi, mengurangi kemiskinan, memberantas korupsi dan lain-lain;

4. Kebijakan publik mungkin berbntuk positif, mungkin pula negatif. Dalam bentuk positif mencakup beberapa bentuk tindakan pemerintah yang dimaksudkan untuk mempengaruhi penyelesaian atau masalah tertentu. Sementara dalam bentuk negatif, kemungkinan melalui keputusan- keputusan pejabat pemerintah untuk bertindak atau tidak melakukan tindakan apapun dalam masalah- masalah dimana campur tangan pemerintah itu sebenarnya justru amat diperlukan. ${ }^{8}$

\section{Tinjauan tentang Peraturan Daerah}

\section{a. Pengertian Peraturan Daerah}

Di dalam wikipedia Bahasa Indonesia, peraturan daerah adalah Peraturan Perundang-Undangan yang dibentuk oleh Dewan Perwakilan Rakyat Daerah dengan persetujuan bersama Kepala Daerah (gubernur, atau bupati/walikota). Peraturan daerah terdiri atas Peraturan Daerah Provinsi, dan Peraturan Daerah Kabupaten/Kota dan berpola mengarah pada tujuan peraturan daerah yang merupakan produk hukum pemerintah daerah, peraturan gubernur dan/atau peraturan bupati sebagai lembaga legislatif, berdasarkan Pasal 5 UndangUndang Nomor 12 Tahun 2011 tentang Pembentukan Peraturan PerundangUndangan yang selanjutnya disebut UU No. 12 Tahun 2011, membentuk peraturan perundang-Undangan harus dilakukan berdasarkan pada asas pembentukan peraturan perundang- undangan yang baik, yang meliputi:

1. Kejelasan tujuan;

2. Kelembagaan atau pejabat pembentuk yang tepat;

3. Kesesuaian antara jenis, hierarki dan materi muatan;

4. Dapat dilaksanakan;

5. Kedayagunaan dan kehasilgunaan;

6. Kejelasan rumusan;

7. Keterbukaan.

\section{Tinjauan tentang Peraturan Kepala Daerah}

Sebagaimana yang dijelaskan di dalam Pasal 1 Angka 11 Undang-Undang Nomor 32 Tahun 2004 tentang Pemerintahan Daerah, peraturan kepala daerah adalah Peraturan Gubernur dan/ atau Peraturan Bupati/Walikota. Selanjutnya dijelaskan pula di dalam Pasal 1 angka 9 Undang- Undang Nomor 28 Tahun 2009 tentang Pajak Daerah dan Retribusi Daerah, menyebutkan bahwa peraturan kepala daerah adalah Peraturan Gubernur dan/atau Peraturan Bupati/Walikota.

Oleh karena itu dapat dilihat lebih jauh kewenangan yang dimiliki Kepala

${ }^{8}$ Ibid, h. 11. 
daerah sebagaimana yang diatur dalam Pasal 65 ayat (2) Undang-Undang Republik Indomesia Nomor 9 Tahun 2015 tentang Perubahan Kedua atas Undang-Undang Nomor 23 Tahun 2014 tentang Pemerintahan Daerah, bahwa kepala daerah dalam melaksanakan tugasnya sebagaimana yang dimaksud pada ayat (1), kepala daerah berwenang:

1) Mengajukan rancangan perda;

2) Menetapkan perda yang telah mendapat persetujuan dari bersama DPRD;

3) Menetapkan Perkada dan keputusan kepala daerah;

4) Mengambil tindakan tertentu dalam keadaan mendesak yang sangat dibutuhkan oleh daerah dan/atau masyarakat;

5) Melaksanakan wewenang lain sesuai peraturan perundang-undangan.

Berdasarkan regulasi tersebut diatas, maka pada Pasal 65 ayat (2) UndangUndang Nomor 9 Tahun 2015 pada poin C, D dan E adalah suatu kewenangan untuk mengeluarkan peraturan kepala daerah yang merupakan manifestasi dari kebijakan publik yang dikeluarkan dikarenakan untuk pelaksanaan peraturan daerah yang aplikatif.

\section{HASIL PENELITIAN DAN PEMBAHASAN}

Evaluasi Implementasi Kebijakan Publik pada Peraturan Daerah Bermasalah Dapat Mewujudkan Sistem Pemerintahan Daerah dengan Asas Otonomi Daerah

Bertolak dari beberapa pendapat para pakar tentang kebijakan publik, termasuk didalamnya bagaimana proses, mekanisme, sampai dengan evaluasi dan implementasinya, maka dapat dilihat bahwa suatu kebijakan publik dalam bentuk peraturan kepala daerah sebagaimana kewenangan yang dimilikinya harus mampu dibuat dan ditetapkan dengan tetap memperhatikan tujuan dari peraturan daerah yang nantinya akan menjadi acuan dari pembuatan kebijakan tersebut.

Kebijakan publik yang akan dibuat tentunya harus melalui tahap-tahap pengambilan kebijakan. Tahap-tahap kebijakan publik menurut William Dunn adalah sebagai berikut: ${ }^{9}$

\section{Penyusunan Agenda}

Agenda setting adalah sebuah fase dan proses yang sangat strategis dalam realitas kebijakan publik. Dalam proses inilah memiliki ruang untuk memaknai apa yang disebut sebagai masalah publik dan prioritas dalam agenda publik dipertarungkan.

\section{Formulasi Kebijakan}

Masalah yang sudah masuk dalam agenda kebijakan kemudian dibahas oleh para pembuat kebijakan. Masalah-masalah tadi didefinisikan untuk kemudian dicari pemecahan masalah yang terbaik. Pemecahan masalah tersebut berasal dari berbagai alternatif atau pilihan kebijakan yang ada. Sama halnya dengan perjuangan suatu masalah untuk masuk dalam agenda kebijakan, dalam tahap perumusan kebijakan masing-masing slternatif bersaing untuk dapat dipilih sebagai kebijakan yang diambil

${ }^{9}$ Op.Cit., h. 156. 
untuk memecahkan masalah.

\section{Adopsi atau Legitimasi Kebijakan}

Tujuan legitimasi adalah untuk memberikan otorisasi pada proses dasar pemerintahan. Jika tindakan legitimasi dalam suatu masyarakat diatur oleh kedaulatan rakyat, warga negara akan mengikuti arahan pemerintah.

\section{Penilaian atau Evaluasi Kebijakan}

Evaluasi kebijakan bisa meliputi tahap perumusan masalah-masalah kebijakan, program-program yang diusulkan untuk menyelesaikan masalah kebijakan, implementasi maupun tahap dampak kebijakan.

\section{Formulasi Kebijakan}

Masalah yang sudah masuk dalam agenda kebijakan kemudian dibahas oleh para pembuat kebijakan. Masalah-masalah tadi didefinisikan untuk kemudian dicari pemecahan masalah yang terbaik. Pemecahan masalah tersebut berasal dari berbagai alternatif atau pilihan kebijakan yang ada. Sama halnya dengan perjuangan suatu masalah untuk masuk dalam agenda kebijakan, dalam tahap perumusan kebijakan masing-masing alternatif bersaing untuk dapat dipilih sebagai kebijakan yang diambil untuk memecahkan masalah.

\section{Adopsi atau Legitimasi Kebijakan}

Tujuan legitimasi adalah untuk memberikan otorisasi pada proses dasar pemerintahan. Jika tindakan legitimasi dalam suatu masyarakat diatur oleh kedaulatan rakyat, warga negara akan mengikuti arahan pemerintah. Namun warga negara harus percaya bahwa tindakan pemerintah yang sah.

\section{Penilaian / Evaluasi Kebijakan}

Secara umum evaluasi kebijakan dapat dikatakan sebagai kegiatan yang menyangkut estimasi atau penilaian kebijakan yang mencakup substansi, implementasi dan dampak. Dalam hal ini , evaluasi dipandang sebagai suatu kegiatan fungsional. Artinya, evaluasi kebijakan tidak hanya dilakukan pada tahap akhir saja, melainkan dilakukan dalam seluruh proses kebijakan.

Sehingga peraturan daerah yang dimaksudkan agar dapat dipahami dan diterapkan dengan peraturan pelaksananya berupa kebijakan publik, dengan melalui prosesproses pengambilan kebijakan dan lain sebagainya sepanjang tidak bertentangan dengan peraturan perundang- undangan yang berada di atasnya, serta tidak melawan hukum, dan tidak melanggar nilai nilai kesusilaan, dan dalam kontesks otonomi daerah. Serta tetap bernafaskan demokrasi

\section{PENUTUP}

Dengan dilaksanakannya evaluasi implementasi dari kebijakan yang timbul tersebut baik melalui kewenangan yang dimiliki kepala daerah secara atributif dalam bentuk freies ermesson, maupun kewenangan yang wajib dilaksanakan ketika peraturan daerah tidak dapat diaplikasikan. Di dalam pembentukan dan keputusan kebijakan tersebut tentu saja harus sesuai dengan tujuan peraturan daerah yang dimaksud, yang 
pada hakikatnya adalah demi kepentingan masyarakat daerah dalam suatu konteks pemerintahan daerah dengan senantiasa melihat azas otonomi daerah, yakni pemberdayaan terhadap masyarakat daerah.

Untuk terwujudnya kebijakan publik yang timbul sebagai manifestasi dari peraturan daerah tersebut, maka diperlukan tetap adanya partisipasi masyarakat yang dalam hal ini merupakan tujuan secara umum peraturan daerah, yakni kesejahteraan masyarakan daerah, yang sesuai dengan nafas penyelenggaraan pemerintahan daerah dengan azas otonomi daerah.

\section{DAFTAR PUSTAKA}

\section{Buku :}

Irawan Suntoro dan Hasan Hariri, Kebijakan Publik, Bandar Lampung: Graha Ilmu, 2015. Sirajuddin, Didik Sukriono dan Winardi, Hukum Pelayanan Publik Berbasis Partisipasi dan Keterbukaan Informasi, 2011.

Surya Fermana, Kebijakan Publik Sebuah Tinjauan Filosofis, AM Media, 2009.

William N. Dunn, Pengantar Analisis Kebijakan Publik Edisi kedua, Gadjah Mada University Press: Cetakan Kelima Maret 2003.

\section{Perundang-Undangan:}

Undang-Undang Nomor 12 Tahun 2011 tentang Pembentukan Peraturan PerundangUndangan

Undang- Undang Nomor 28 Tahun 2009 tentang Pajak Daerah dan Retribusi Daerah Undang-Undang Nomor 32 Tahun 2004 tentang Pemerintahan Daerah 